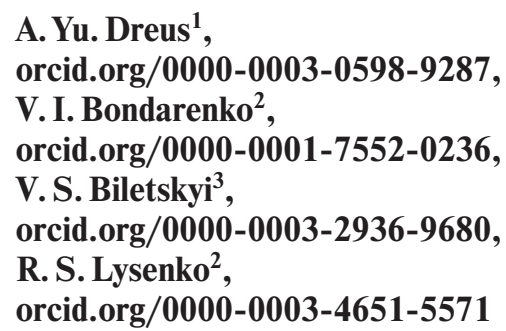

1 - Oles Honchar Dnipro National University, Dnipro, Ukraine, e-mail: dreus.andrii@gmail.com

2 - Dnipro University of Technology, Dnipro, Ukraine, e-mail: vdomna@yahoo.com

3 - National Technical University "Kharkiv Polytechnic Institute", Kharkiv, Ukraine

\title{
MATHEMATICAL SIMULATION OF HEAT AND MASS EXCHANGE PROCESSES DURING DISSOCIATION OF GAS HYDRATES IN A POROUS MEDIUM
}

Purpose. The development of methodology of research and analysis of heat and mass exchange processes in a hydrate-containing porous rock layer in case of a pressure drop at its boundary.

Methodology. Mathematical simulation, computational experiment.

Findings. The mathematical simulation of thermophysical processes during the dissociation of gas hydrate in a porous rock layer is presented. The case of gas hydrate dissociation in a porous rock layer, which exists in a stable state under the influence of relatively high initial temperature and pressure factors, is investigated. Numerical studies on the temperature and pressure patterns during the gas hydrate dissociation are performed. The nonstationary distribution of temperature and pressure along a porous rock layer during the dissociation of gas hydrate due to pressure drop at its boundary is presented. The advancement rate of the gas hydrate dissociation front and the change in the size of the dissociated gas hydrate area over the time are determined.

Originality. The algorithm is proposed for calculating the pressure and temperature fields in a porous rock layer in the case when the temperature of the stable gas hydrate is higher than its dissociation temperature. The factor that ensures the dissociation of gas hydrate is the pressure drop at the rock layer boundary. The effect of the endothermal reaction of gas hydrate dissociation on the heat exchange processes in the porous rock layer is presented. It is shown that the temperature and pressure values determining the gas hydrate dissociation point are changed as the front of the phase transition advances.

Practical value. The proposed mathematical model and calculation algorithm can be used to predict the time characteristics and sizes of the gas hydrate dissociation zones around production wells.

Keywords: gas hydrates dissociation, heat exchange process, endothermal reaction, hydrate dissociation, pressure drop

Introduction. Gas hydrates are one of the most promising energy reserves of humanity. The rapid growth of R\&D work in the field of gas hydrate technologies worldwide [1] is caused by this factor. The development of gas hydrate deposits is an important issue for the Ukrainian economy, which significantly depends on the import of energy resources, particularly natural gas. At the same time, known gas hydrate deposits are a significant energy reserve. They are located both at the bottom of the Black Sea and on the mainland - in deep coal mines. In particular, one of the features of coal deposits in Ukraine is the large occurrence depth (up to $1 \mathrm{~km}$ or more). This property creates the prerequisites for the formation of gas hydrates in coal seams. In this connection, the implementation of studies on the development of gas hydrate technologies is an urgent and important task. An integral part of such studies is theoretical investigations of physical and chemical processes occurring during the dissociation of gas hydrates.

The fundamentals of the theory of gas hydrates are formulated by Yu.F. Makogon. (Makogon, Yu.F., Hydrates of Hydrocarbons, 1997, Penn Well, Tulsa, USA). Today, there are a large number of experimental and theoretical studies in this direction. Extensive information on methods, technologies, and also approaches to the description of physical mechanisms during the formation and dissociation of gas hydrates is presented in the paper [2]. Despite significant progress in the theory and practice of gas hydrate technologies, many issues related to the physical and chemical processes during hydrate formation, are still not fully understood. In the paper [3], the significant role of thermal and hydro-mechanical phenomena in the overall physical interpretation is noted. One of the effective tools for studying such phenomena is the mathematical simulation of heat and mass exchange processes. However, the variety of physical models in the formation and dissociation of gas hydrates results in different approaches to the mathematical description of processes.

(C) Dreus A. Yu., Bondarenko V. I., Biletskyi V. S., Lysenko R. S., 2020
It is a common fact that the dissociation process of gas hydrates into gas and water occurs due to changes in temperature and/or pressure. Natural accumulations of gas hydrates are often formed at deep depths in the porous rock environment [4], where they can exist at relatively high temperatures and pressures. In case when the integrity of the formation is violated at the free boundary, the thermodynamic equilibrium is violated and the phase transformation process begins.

In this paper, heat and mass exchange processes in a porous hydrate-containing rock layer during its destruction are considered. As a factor initiating the dissociation process, a pressure drop at the boundary is taken. One of the features of the problem statement is the assumption that gas hydrate exists at relatively high temperatures. In the paper, a mathematical model in the framework of the phenomenological approach is proposed, and the dynamics of the temperature and pressure fields during the change of thermodynamic conditions at the boundary is investigated.

Literature review. An extensive analysis of various approaches to the mathematical simulation of processes occurring during the exploration and exploitation of natural gas hydrates was performed in the paper [5]. It should be noted that in most cases, mathematical models are complex systems of differential equations, the solution of which in the general case is possible only by numerical methods.

In many cases, the simulation of physical processes during phase transitions "hydrate - gas + water" is based on the use of kinetic equations. The review of analytical, semi-empirical, and numerical kinetic models of hydrate formation is given in the paper [6]. The kinetic model of the formation of gas hydrate particles at low temperatures was considered in detail in the paper [7]. The non-deterministic stochastic approach for modeling the kinetics of gas hydrate formation was proposed in the paper [8].

During the simulation of the formation and dissociation processes of gas hydrates in pipelines, quite complex models of the dynamics of multiphase flows are often used [9]. In this 
case, the knowledge of the flow regime is essential, which requires the use of additional empirical data from the experiment [10]. The possibility of using the hydraulic approximation for the simulation of such processes was considered in the paper [11].

The phenomenological approach for studying the dissociation processes of gas hydrates in porous media based on the equations of continuum mechanics and the heat and mass exchange was considered in the paper [12]. Such models are used to simulate the processes of gas hydrate dissociation during the development of natural deposits. The formation mechanisms and the quantitative description of the processes of formation and dissociation of gas hydrates in offshore fields are presented in the paper [13]. Mathematical models at an adequate quality level were developed to study the gas hydrate dissociation in porous media under conditions of both low temperatures [14] and heat supply from outside [15]. Heat exchange processes in wells during the development of natural gas hydrate deposits are modeled in the paper [16]. In the paper [17], the Stefan model was used to study the dynamics of phase transformations during the dissociation of natural gas hydrates. It should be noted that in most known models, the dissociation processes of gas hydrates are caused by the thermal factor. The effect of pressure variation on the dynamics of phase transitions in a hydrate-containing porous medium is much less studied. In the present paper, the attempt to simulate mathematically the hydrate dissociation process due to the pressure drop at the boundary of the porous formation is made.

It should be noted that the number of works on experimental studies on the dynamics of temperature, concentration and pressure fields in porous media saturated with gas hydrates is limited. This makes it difficult to verify mathematical models. However, the numerical study is quite effective and sometimes the most productive method for assessing physical phenomena in deep natural gas hydrate deposits.

Formulation of the problem. Gas hydrates are clathrate compounds in which gas molecules are enclosed in the cavity of the polyhedral frame constructed by the water molecules. The physical properties of such crystalline compounds are close to the properties of ice. The essential feature of methane gas hydrates is their stability under a positive temperature and external pressure of several megapascals.

It is known that at significant depths (1000 $\mathrm{m}$ and more), the pressure in the rocks can reach quite large values. Under such conditions, gas hydrates can exist at relatively high temperatures. Among other factors, the abovementioned studies confirm that the thermobaric conditions of occurrence of coal seams cover the area of stable existence of gas hydrates. The methane content in coal seams increases with increasing depth of occurrence. The formation pressure of methane, on average, linearly depends on depth. For different layers, the pressure is in the range of $(0.4-1) \cdot \gamma h$, where $\gamma h$ is the rock pressure of the undisturbed layer, and where $\gamma=25000 \mathrm{~N} / \mathrm{m}^{3}$ is the average specific weight of rocks, and $h$ is the depth of the layer from the land surface. The hydrate dissociation in the porous environment of coal can cause dangerous gas-dynamic phenomena. At the moment, these phenomena cannot be fully explained within the framework of existing models of methane behavior in the porous structure of coal. Consequently, the simulation problem of heat and mass exchange processes in the hydrate-containing layers is important from the point of prediction of the explosive situations in mines.

In the dissociation process of gas hydrate a three-phase system occurs consisting of the gas phase, undissociated hydrate and liquid water. In practically important cases, the solubility of methane in water and the partial pressure of water vapor in the gas phase can be neglected. In this case, the phase equilibrium curve is described by the Clausius-Clapeyron equation

$$
\frac{\mathrm{d} T}{\mathrm{~d} p}=\frac{\Delta H}{T\left(v_{2}-v_{1}\right)},
$$

where $T, P$ are the temperature and pressure; $\Delta H$ is the enthalpy; $v_{2}, v_{1}$ are the volumes of the substance in various phase states.

The latent heat of gas hydrates dissociation $L$ can be defined as the decomposition enthalpy $\Delta H$ of the chemical compound $\mathrm{CH}_{4} \cdot n \mathrm{H}_{2} \mathrm{O}$ into pure components $\mathrm{CH}_{4}$ and $\mathrm{H}_{2} \mathrm{O}$ under equilibrium temperature and pressure. When the composition $\mathrm{CH}_{4} \cdot 6 \mathrm{H}_{2} \mathrm{O}$ of methane gas hydrate is decomposed into gas and water, $\Delta H \approx 54 \mathrm{~kJ} / \mathrm{kg}$. The dissociation heat of the gas hydrate exceeds the fusion heat of ordinary ice, but much less than the combustion heat of the same amount of methane $\Delta H=890 \mathrm{~kJ} / \mathrm{kg}$.

The core methods for developing gas hydrate deposits are based on their dissociation, i.e. decomposition under the formation conditions. In such a way, the efficiency of the technological process is associated with heat and mass exchange processes in the porous formation environment. The gas hydrates dissociation process directly in the formation conditions can be initiated by various methods: temperature increase, use of chemical inhibitors, pressure reduction, or integrated method. The thermal method and the injection of chemical inhibitors (salt solution $\mathrm{CaCl}_{2}$, alcohol (methanol), and others) into the formation are most commonly used in the development of onshore fields.

A promising method for gas production from gas hydrate formation can also be the pressure reduction method. When applying the depression method for developing gas hydrate deposits, it is necessary that the pressure in the formation becomes lower than the equilibrium pressure of hydrate dissociation. In this case, the gas hydrate decomposes into gas and water, while absorbing heat. However, with this method of reservoir development, the phenomenon of self-preservation of gas hydrate may occur. In particular, with isothermal pressure relief, the dissociation process will slow down, and the hydrate will be in a metastable state for a sufficiently long time. Thus, the study of heat and mass exchange processes is an important task in the context of the search for effective modes of depression of the porous formation.

The objectives of studying the gas hydrates dissociation processes in a porous rock environment around wells are generated by practical interest. Insufficient thermal insulation of wells passing through a hydrate-containing formation can lead to gas hydrate dissociation, accompanied by an increase in pressure. Hydrate dissociation occurs in the near well-bore area of the production well. During the operation of the production well, the pressure in its shaft is less than the formation pressure, and conditions for the hydrates dissociation may arise. Another problem related to the heat transfer processes is the formation of hydrates during the injection. When cold liquid carbon dioxide is injected into a depleted natural gas field, carbon dioxide hydrate may be formed. All these problems can be investigated in the first approximation by one-dimensional mathematical models. Fig. 1 shows the general scheme for the problem of gas hydrates dissociation around the well in the axisymmetric case.

Based on the above concepts, the problem of gas hydrates dissociation with the pressure drop at the boundary is formulated.

An unspecified deep horizontal rock layer is presented as a porous medium with a constant porosity $\mathrm{m}$. The rock contains

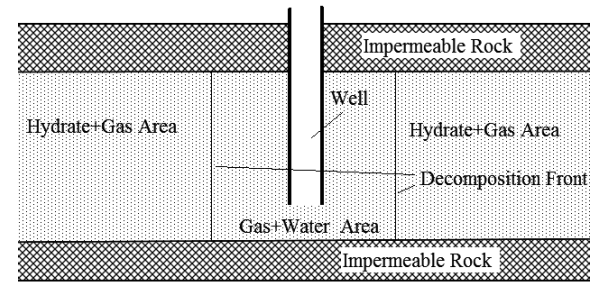

Fig. 1. The scheme of the gas hydrate layer in the rock mass 
gas and hydrate at the initial positive temperature $T_{0}$ and high pressure $P_{0}$. At the initial moment of time, the integrity of the rock is violated, for example, by drilling. At the free boundary, the pressure drops to a value of $P_{w}$ below the dissociation point of the gas hydrate $P_{f}$. Due to the pressure drop, the decomposition process of the gas hydrate into gas and water is started.

In the general case, when the gas hydrate is dissociated in the porous medium, three areas can be formed: the area containing gas and hydrate in a stable state; the transition area, where dissociation takes place, and at the same time gas, hydrate and water are present; and the area saturated with water and gas. However, as it is noted in the paper [18], in many cases, the dissociation process occurs almost instantly. Therefore, the intermediate area degenerates into the frontal surface. This surface is characterized by the values of $P_{f}$ and $T_{f}$ corresponding to the dissociation point.

If the adjacent upper and lower layers of rocks are impermeable to gas, then the dissociation process will occur only in the direction perpendicular to the free surface. Assume that the $x$ coordinate axis is directed along the layer, and the beginning of the axis is located on the free boundary (Fig. 2).

The phase transition line $\xi$ separates area $1-$ gas + water, and area 2 - hydrate + gas. It is assumed that the temperature of the atmosphere contacting the free boundary does not differ significantly from the layer temperature $T_{w} \approx T_{0}$, which is quite possible at great depths. Since the phase state is determined not only by temperature, but by the pair of thermodynamic parameters $(T, P)$, gas hydrate dissociation can occur at the phase transition temperature below the initial temperature of the gas hydrate $T_{f}<T_{0}$ [19]. At the same time, the hydrate dissociation process is endothermic, as a result of which thermal energy will be absorbed on the phase transition line, which in turn affects pressure. Thus, the thermodynamic parameters determining the dissociation process will be also changed with time.

Fundamental equations. When constructing the mathematical model, the single-temperature model of the multiphase medium is used, i.e. water, hydrate, gas and rock have the same temperature at the selected point.

The laws of conservation of mass and energy, as well as Darcy's filtration law and gas state equation will be used to describe the gas hydrates dissociation in the porous medium. The system of equations describing the processes of heat and mass exchange is written as follows:

- for area 1

$$
\begin{gathered}
m \frac{\partial}{\partial \tau}\left(1-S_{w}\right) \rho_{g}+\operatorname{div} \vec{v}_{g} \rho_{g}=0 ; \\
m \frac{\partial S_{w}}{\partial \tau}+\operatorname{div} \vec{v}_{w}=0 ; \\
(c \rho)_{1} \frac{\partial T}{\partial \tau}+\rho_{g} c_{g} \vec{v}_{g} \operatorname{grad} T=\operatorname{div}\left(\lambda_{1} \operatorname{grad} T\right) ; \\
\vec{v}_{j}=-\frac{k}{\mu_{j}} \operatorname{grad} P=0 ; \\
P=\rho_{g} R T, \quad j=g, w ;
\end{gathered}
$$

- for area 2

$$
m \frac{\partial}{\partial \tau}\left(1-S_{h}\right) \rho_{g}+\operatorname{div} \vec{v}_{g} \rho_{g}=0 ;
$$

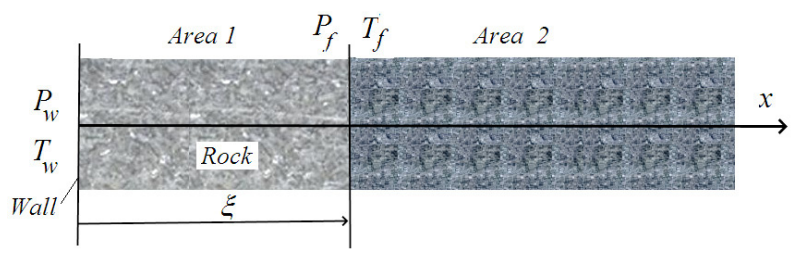

Fig. 2. Scheme for calculating the gas hydrate dissociation in the porous layer

$$
\begin{gathered}
(c \rho)_{2} \frac{\partial T}{\partial \tau}+\rho_{g} c_{v} \vec{v}_{g} \operatorname{grad} T=\operatorname{div}\left(\lambda_{2} \operatorname{grad} T\right) ; \\
\vec{v}_{g}=-\frac{k}{\mu_{g}} \operatorname{grad} P ; \\
P=\rho_{g} R T,
\end{gathered}
$$

where $T$ is the temperature; $P$ is the pressure; $\tau$ is the time; $\rho$ is the density; $c$ is the heat capacity; $v$ is the flow rate; $\lambda$ is the thermal conductivity; $k$ is the medium permeability; $\mu$ is the dynamic viscosity coefficient; $S$ is the pore saturation with the corresponding phase; $R$ is the universal gas constant, the indices $h, g, w$ are referred to hydrate, gas, and water, respectively. Balance conditions are also added to system (1-9)

$$
\left.\begin{array}{ll}
S_{g}+S_{w}=1, & 0 \leq x<\xi(\tau) \\
S_{g}+S_{h}=1, & \xi(\tau) \leq x<\infty
\end{array}\right\} .
$$

The first equations of system (10) represent the mass balance in the zone of dissociated gas hydrate (area 1 in Fig. 1), and the second equation - in the zone of stable gas hydrate (area 2 in Fig. 2).

The thermophysical properties of the porous medium are determined from the relations

$$
\begin{gathered}
\lambda_{1}=m\left(1-S_{w}\right) \lambda_{g}+m S_{w} \lambda_{w}+(1-m) \lambda_{s} ; \\
(c \rho)_{1}=m S_{w} \rho_{w} c_{w}+m\left(1-S_{w}\right) \rho_{g} c_{g}+(1-m) \rho_{s} c_{s} ; \\
\lambda_{2}=m\left(1-S_{h}\right) \lambda_{g}+m S_{h} l_{h}+(1-m) \lambda_{s} ; \\
(c \rho)_{2}=m\left(1-S_{h}\right) \rho_{g} c_{g}+m S_{h} \rho_{h} c_{h}+(1-m) \rho_{s} c_{s},
\end{gathered}
$$

where the index $s$ is referred to the rock.

Let us consider the processes on the surface of the phase transition $\xi$. On this surface, the hydrate saturation jumps from the value $S_{h}=S_{h 0}$ to $S_{h}=0$, and the thermodynamic parameters take values corresponding to the phase transition point

$$
T=T_{f} ; \quad P=P_{f} .
$$

A large number of works are devoted to the determination of the relationship between the values $P_{f}$ and $T_{f}$ characterizing the equilibrium state. Basically, the relationship between these parameters is described by empirical expressions. The review of such expressions is presented in the monograph [20]. The Antoine equation will be used for the connection of these parameters

$$
T_{f}=\frac{9459}{49.3185-\ln P_{f}} .
$$

The mass and heat flows will undergo a discontinuity on the front surface due to the absorption of heat and the gas hydrate decomposition into gas and water. The equations of mass and energy balance on the surface have the form

$$
\begin{gathered}
\left.\vec{n} \vec{J}_{w}\right|_{\xi}=W_{w} ; \\
\left.\vec{n}\left(\vec{J}_{g 1}-\vec{J}_{g 2}\right)\right|_{\xi}=W_{g} ; \\
\left.\vec{n}\left(\vec{q}_{1}-\vec{q}_{2}\right)\right|_{\xi}=H,
\end{gathered}
$$

where $\vec{n}$ is the normal unit vector to the frontal surface; $W_{w}=$ $=-m \rho_{h}(1-G) \frac{\partial S_{h}}{\partial \tau} ; \quad W_{g}=-m \rho_{h} G \frac{\partial S_{h}}{\partial \tau} ; \quad H=\rho_{h} L \frac{\mathrm{d} \xi}{\mathrm{d} \tau} ; G$ is the mass concentration of gas in the hydrate; $L$ is the latent heat of the phase transition.

Since the thermophysical characteristics of the porous medium are determined mainly by the properties of the rock, it is assumed that $\lambda_{1}=\lambda_{2}=$ const, $\left(c p_{1}\right)=\left(c p_{2}\right)=$ const. It will be considered that the transfer processes are carried out mainly due to the movement of gas, while water is poorly movable. Taking into account the assumptions, the mathematical model 
of heat and mass exchange processes for the one-dimensional semi-infinite layer based on system (1-9) is written as follows

$$
\begin{gathered}
\frac{\partial P_{1}}{\partial \tau}=\frac{k_{g}}{m \mu_{g} S_{g}} \frac{\partial}{\partial x}\left(P_{1} \frac{\partial P_{1}}{\partial x}\right), \quad 0<x<\xi(\tau) \\
(c \rho)_{1} \frac{\partial T_{1}}{\partial \tau}-\frac{c_{g} k_{g}}{m \mu_{g}} \frac{P_{1}}{R_{g} T_{1}} \frac{\partial P_{1}}{\partial x} \frac{\partial T_{1}}{\partial x}=\frac{\partial}{\partial x}\left(\lambda_{1} \frac{\partial T_{1}}{\partial x}\right), \quad 0<x<\xi(\tau) \\
\frac{\partial P_{2}}{\partial \tau}=\frac{k_{g}}{m \mu_{g} S_{g}} \frac{\partial}{\partial x}\left(P_{2} \frac{\partial P_{2}}{\partial x}\right), \quad \xi(\tau)<x<\infty \\
(c \rho)_{2} \frac{\partial T_{2}}{\partial \tau}-\frac{c_{g} k_{g}}{m \mu_{g}} \frac{P_{2}}{R_{g} T_{2}} \frac{\partial P_{2}}{\partial x} \frac{\partial T_{2}}{\partial x}=\frac{\partial}{\partial x}\left(\lambda_{2} \frac{\partial T_{2}}{\partial x}\right) \\
\xi(\tau)<x<\infty
\end{gathered}
$$

The initial conditions for the system (16-19) have the following form

$$
\begin{array}{ll}
T_{1}(x, 0)=T_{0} ; & P_{1}(x, 0)=P_{0} ; \\
T_{2}(x, 0)=T_{0} ; & P_{2}(x, 0)=P_{0} .
\end{array}
$$

On the phase transition surface, the following conditions are formulated based on balance equations $(14,15)$

$$
\begin{gathered}
\left.\left(\frac{k_{g}}{\mu_{g}} \frac{\partial P_{1}}{\partial x}-\frac{k_{g}}{\mu_{g}} \frac{\partial P_{2}}{\partial x}\right)\right|_{\xi}=\left.m\left(S_{g 1}-S_{g 2}-\frac{\rho_{h}}{\rho_{g}} G S_{h}\right)\right|_{\xi} \frac{d \xi}{d \tau} \\
\left.\left(\lambda_{1} \frac{\partial T_{1}}{\partial x}-\lambda_{2} \frac{\partial T_{2}}{\partial x}\right)\right|_{\xi}=m \rho_{h} L \frac{d \xi}{d \tau}
\end{gathered}
$$

The boundary conditions for (16-19) are written like

$$
\begin{gathered}
-\left.\lambda_{2} \frac{\partial T_{2}}{\partial x}\right|_{x=0}=\alpha\left(\left.T_{2}\right|_{x=0}-T_{w}\right) ;\left.\quad P_{2}\right|_{x=0}=P_{w} ; \\
\left.T_{1}\right|_{x \rightarrow \infty}=T_{0} ;\left.\quad P_{1}\right|_{x \rightarrow \infty}=P_{0},
\end{gathered}
$$

where $\alpha$ is the heat exchange between the porous layer and the external atmosphere, which can be determined by the technique proposed in the paper [21].

The $k_{g}$ value can be determined from the Cozeny-Karman relation (Carman, P. C. Permeability of saturated sands, soils and clays. The Journal of Agricultural Science, 1939), which is widely used in the study of filtration processes in porous media

$$
k_{g}=k_{0} S_{g}^{3},
$$

where $k_{0}$ is the absolute permeability of the layer.

System (16-23) is the system of nonlinear differential equations. In the general case, to solve problem (16-23), it is necessary to apply numerical methods [22]. In this case, both marching methods and methods with the selection of the phase transition front can be used. In the present work, the method of the phase transition front "capturing" in the node is used. The feature of the algorithm used in this work has lied in the fact that to determine the advance rate of the phase transition front the equation (23) is used. In most known works, the thermal condition (22) is used to determine this value. The general scheme of the calculation algorithm is presented in Fig. 3.

In accordance with the algorithm in Fig. 3, at each time step, the following sequence of operations is carried out. Since the physical factor that leads to the beginning of the gas hydrate dissociation is pressure, the advance rate of the phase transition front is determined from equation (21). Then the temperature drop in consequence of the endothermic dissociation reaction is determined. After that, the pressure and temperature fields are determined based on the numerical solution of the differential equations system.

Results. Let us consider the heat and mass exchange processes in the porous rock layer with $m=0.022$ during the gas

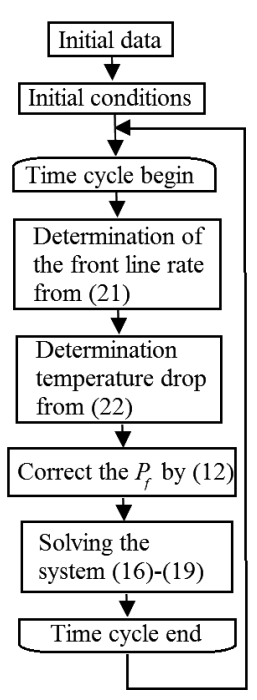

\section{Fig. 3. Calculation algorithm scheme}

hydrate dissociation. It is assumed that under conditions of the abnormally high formation pressure of $P_{0}=10 \mathrm{MPa}$, the stable methane hydrate is presented in the formation at the positive temperature of $T_{0}=283 \mathrm{~K}$. The initial concentration of gas in the hydrate is $G=0.2$. At some initial moment of time, the formation is destructed, and the pressure drops to a value of $P_{w} \approx 0.1 \mathrm{MPa}$ at the free boundary of the massif. Due to the violation of thermodynamic equilibrium, decomposition of the gas hydrate into gas and water is initiated. The pressure of the phase transition at the given initial temperature is $P_{f}=9.56 \mathrm{MPa}$. Since hydrate dissociation is the endothermic reaction with the absorption of heat, as a result, the drop in temperature will arise.

The initial data for the calculation are taken as follows: $k_{0}=10^{-16} \mathrm{~m}^{2}, L=5 \cdot 10^{5} \mathrm{~J} / \mathrm{kg}, S_{w 0}=0.9, R_{g}=520 \mathrm{~J} /(\mathrm{kg} \cdot \mathrm{K}), \rho_{g}=$ $=1.2 \mathrm{~kg} / \mathrm{m}^{3}, \rho_{h}=900 \mathrm{~kg} / \mathrm{m}^{3}, \rho_{w}=980 \mathrm{~kg} / \mathrm{m}^{3}, \rho_{s}=2000 \mathrm{~kg} / \mathrm{m}^{3}$, $\lambda_{g}=0.6 \mathrm{~W} /(\mathrm{m} \cdot \mathrm{K}), \lambda_{h}=2.11 \mathrm{~W} /(\mathrm{m} \cdot \mathrm{K}), \lambda_{w}=0.58 \mathrm{~W} /(\mathrm{m} \cdot \mathrm{K})$, $\mu_{g}=10^{-5} \mathrm{~Pa} \cdot \mathrm{sec}, c_{g}=1560 \mathrm{~J} /(\mathrm{kg} \cdot \mathrm{K}), c_{h}=2500 \mathrm{~J} /(\mathrm{kg} \cdot \mathrm{K})$, $c_{w}=4200 \mathrm{~J} /(\mathrm{kg} \cdot \mathrm{K}), c_{s}=1000 \mathrm{~J} /(\mathrm{kg} \cdot \mathrm{K})$.

The results of calculating the temperature field along the porous formation according to the above algorithm are presented in Fig. 4. The results of the pressure field calculation are shown in Fig. 5.

As can be seen from the data in Fig. 4, the temperature drop occurs due to the heat absorption during the endothermic dissociation of gas hydrate. As the simulation results show, 10 hours after the start of the process, the temperature at the phase transition front reaches $277.2 \mathrm{~K}$, and the corre-

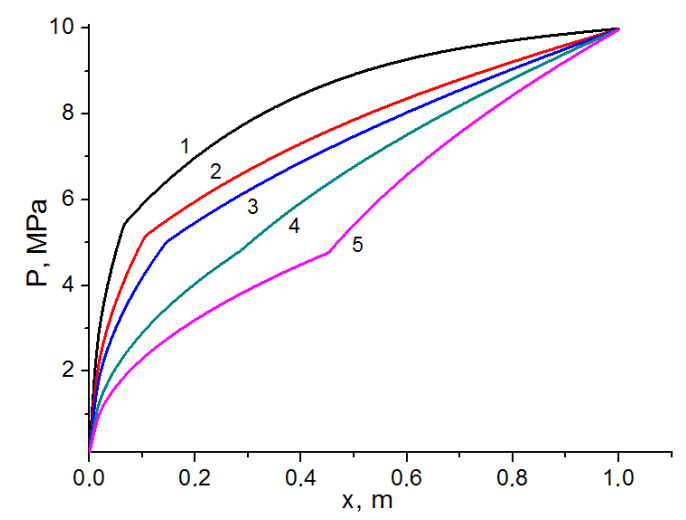

Fig. 4. Distribution of the temperature $T$ in the porous layer during the gas hydrate dissociation:

1 - 10 min; $2-30$ min; $3-1$ hour; $4-4$ hours; $5-10$ hours 


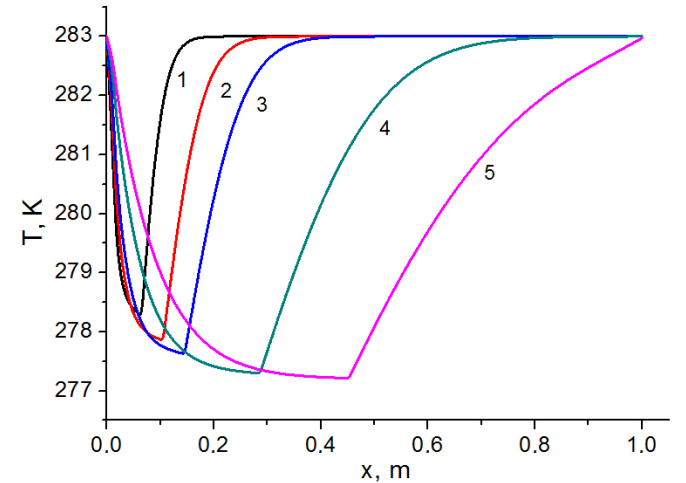

Fig. 5. Distribution of the pressure P in the porous layer during the gas hydrate dissociation:

1 - 10 min; $2-30$ min; $3-1$ hour; $4-4$ hours; $5-10$ hours

sponding pressure becomes 4.4 MPa. Consequently, the local area of reduced temperature with the minimum at the phase transition point is formed in the porous layer. As a result, the pressure value, at which the hydrate dissociates, also decreases (Fig. 5).

Fig. 5 shows that the value of the phase transition pressure is much lower than the initial one, but exceeds the pressure on the free surface. It should be noted that the pressure drop across the thickness of the dissociated layer will contribute to the appearance of the gas stream. The released gas volume will be filtered in the direction of the free surface in proportion to the pressure gradient value.

Fig. 6 shows the change in the advancement rate of the phase transition front over time.

As can be seen from the data in Fig. 6, the advancement rate of the phase transition front decreases over time. Consequently, a growth rate reduction of the area, in which the gas hydrate decomposes into gas and water, will occur. It should be expected that over time the advancement rate of the phase transition front will be asymptotically tended to a certain constant value. Fig. 7 shows the dynamics of the position of the phase transition front over time, which allows us to estimate the size of the area of dissociated gas hydrate.

As can be seen from the data in Fig. 7, the increase in the dissociation area over time is nonlinear. During 10 hours, the phase transition line has advanced approximately on $0.45 \mathrm{~m}$ into the depth of the layer. The increase in the dissociated gas hydrate area decreases over time. It should be noted that the above results correspond to the given porosity of the layer $m=0.022$. Obviously, the porosity is the parameter that can significantly affect the rate of the dissociation front.

The advancement rate of the dissociation front of the gas hydrate and the parameters of the dissociation area are impor-

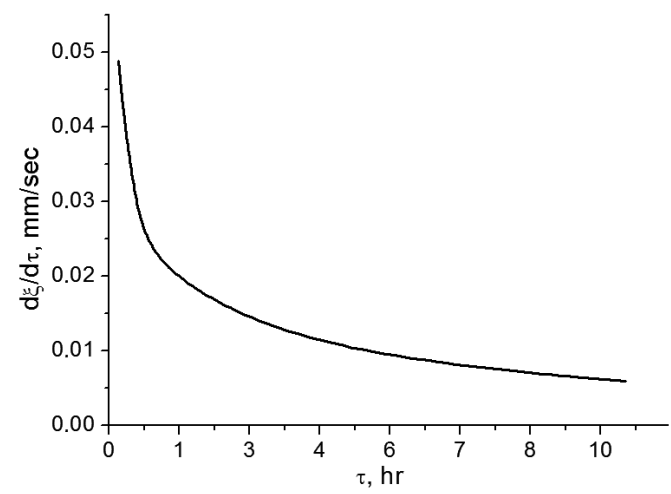

Fig. 6. The change in the advancement rate of the phase transition front over time

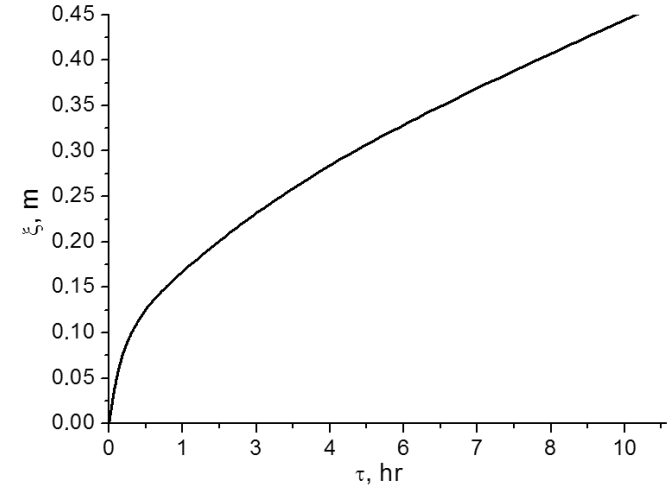

Fig. 7. The dependence of the position of the phase transition front on time

tant technological characteristics of the process. These parameters make it possible to ensure the stable production rate of wells during the development of gas hydrate deposits and to predict their location.

Conclusions. The presented mathematical model and calculation algorithm enable to study the heat exchange processes in the porous rock layer during the gas hydrates dissociation. The case of gas hydrate dissociation in the porous rock layer under the initial high temperatures and pressures is investigated.

It is shown that due to the endothermic reaction of dissociation and heat absorption, the phase transition point, which is determined by pressure and temperature, changes its value over time. In this case, the temperature and pressure drop significantly. The local area of low temperature is formed.

It is shown that for the accepted initial data, the advancement rate of the phase transition front line is decreased from the value of $0.048 \mathrm{~mm} / \mathrm{s}$ in the initial period of the dissociation process up to $0.006 \mathrm{~mm} / \mathrm{s}$. Therewith, the dissociation area of the gas hydrate is $0.45 \mathrm{~m}$ over 10 hours after the beginning of the dissociation process.

The results of this work may be of interest for estimating the rate of gas hydrate dissociation in porous rocks and evaluating the geometric characteristics of the dissociation area in the technologies of gas hydrate deposits development.

\section{References.}

1. Hanushevych, K., \& Srivastava, V. (2017). Coalbed methane: places of origin, perspectives of extraction, alternative methods of transportation with the use of gas hydrate and nanotechnologies. Mining of Mineral Deposits, 11(3), 23-33. https://doi.org/10.15407/mining11.03.023.

2. Li, X.-S., Xu, C.-G., Zhang, Y., Ruan, X.-K., Li, G., \& Wang, Y. (2016). Investigation into gas production from natural gas hydrate: A review. Applied Energy, (172), 286-322. https://doi.org/10.1016/j.apenergy.2016.03.101.

3. Sánchez, M., Santamarina, C., Teymouri, M., \& Gai, X. (2018). Coupled numerical modeling of gas hydrate bearing sediments: from laboratory to field-scale analyses. Journal of Geophysical Research: Solid Earth. https://doi. org/10.1029/2018jb015966.

4. Sai, K., Malanchuk, Z., Petlovanyi, M., Saik, P., \& Lozynskyi, V. (2019). Research of Thermodynamic Conditions for Gas Hydrates Formation from Methane in the Coal Mines. Solid State Phenomena, (291), 155-172. https://doi. org/10.4028/www.scientific.net/SSP.291.155.

5. Sun, Y., Lü, X., \& Guo, W. (2014). A review on simulation models for exploration and exploitation of natural gas hydrate. Arabian Journal of Geoscienes, (7), 2199-2214. https://doi. org/10.1007/s12517-014-1294-1.

6. Yin, Z., Khurana, M., Tan, H. K., \& Linga, P. (2018). A review of gas hydrate growth kinetic models. Chemical En- 
gineering Journal, (342), 9-29. https://doi.org/10.1016/i. cej.2018.01.120.

7. Vlasov, V. A. (2015). Diffusion model of gas hydrate formation from ice. Heat and Mass Transfer, 52(3), 531-537. https:// doi.org/10.1007/s00231-015-1575-6.

8. Klymenko, V. (2019). Modeling of the kinetics of the gas hydrates formation on the basis of a stochastic approach. Solid State Phenomena, (291), 98-109. https://doi.org/10.4028/ www.scientific.net/SSP.291.980.

9. Lorenzo, M.D., Aman, Z.M., Kozielski, K., Norris, B. W. E., Johns, M. L., \& May, E. F. (2018). Modelling hydrate deposition and sloughing in gas-dominant pipelines. Journal of Chemical Thermodynamics, (117), 81-90. https:// doi.org/10.1016/i.jct.2017.08.038.

10. Rao, Y., Ding, B., Wang, S., Wang, Z., \& Zhou, S. (2019). Flow pattern and pressure drop of gas-liquid twophase swirl flow in a horizontal pipe. Journal of Central South University, 26(9), 2528-2542. https://doi.org/10.1007/ s11771-019-4192-6.

11. Bondarev, E., Rozhin, I., \& Argunova, K. (2019). Problem of conjugate heat transfer between main gas pipeline and frozen ground. E3S Web of Conferences, (102), 01001. https://doi. org/10.1051/e3sconf/201910201001.

12. Tsypkin, G. G. (2017). Formation of the impermeable layer in the process of methane hydrate dissociation in porous media. Fluid Dynamics, (52), 657-665. https://doi.org/10.1134/ $\underline{\mathrm{S} 0015462817050076 .}$

13. Haiko, H., \& Pyha, L. (2017). Shielded development of bottom gas hydrates. Mining of Mineral Deposits, 11(3), 117123. https://doi.org/10.15407/mining11.03.117.

14. Lobkovskii, L. I., \& Ramazanov, M. M. (2018). Front Regime of Heat and Mass Transfer in a Gas Hydrate Reservoir under the Negative Temperature Conditions. Fluid Dynamics, 53(4), 517-530. https://doi.org/10.1134/s0015462818040092.

15. Shagapov, V.S., Khasanov, M.K., Musakaev, N.G., \& Duong, N.H. (2017). Theoretical research of the gas hydrate deposits development using the injection of carbon dioxide. International Journal of Heat and Mass Transfer, (107), 347357. https://doi.org/10.1016/j.ijheatmasstransfer.2016.11.034. 16. Yu, L., Xu, Y., Gong, Z., Huang, F., Zhang, L., \& Ren, S. (2018). Experimental study and numerical modeling of methane hydrate dissociation and gas invasion during drilling through hydrate bearing formations. Journal of Petroleum Science and Engineering, (168), 507-520. https://doi.org/10.1016/j. petrol.2018.05.046.

17. Li, M., Fan, S., Su, Y., Ezekiel, J., Lu, M., \& Zhang, L. (2015). Mathematical models of the heat-water dissociation of natural gas hydrates considering a moving Stefan boundary. Energy, 90, 202-207. https://doi.org/10.1016/i.energy.2015.05.064. 18. Bondarenko, V., Kovalevska, I., Astafiev, D., \& Malova, O. (2018). Examination of Phase Transition of Mine Methane to Gas Hydrates and their Sudden Failure - Percy Bridgman's Effect. Solid State Phenomena, 277, 137-146. https:// doi.org/10.4028/www.scientific.net/ssp.277.137.

19. Bondarenko, V., Sai, K., Prokopenko, K., \& Zhuravlov, D. (2018). Thermodynamic and geomechanical processes research in the development of gas hydrate deposits in the conditions of the Black Sea. Mining of Mineral Deposits, 12(2), 104-115. https://doi.org/10.15407/mining12.02.104.

20. Ahmadi, A. M., \& Bahadori, A. (2017). Gas Hydrates. Fluid Phase Behavior for Conventional and Unconventional Oil and Gas Reservoirs, (pp. 405-444). Gulf Professional Publishing. https://doi.org/10.1016/B978-0-12-803437-8.00008-7.

21. Bulat, A., Blyuss, B., Dreus, A., Liu, B., \& Dziuba, S. (2019). Modelling of deep wells thermal modes, Mining of Mineral Deposits, 13(1), 58-65. https://doi.org/10.33271/ mining13.01.058.

22. Kozhevnikov, A.A., Sudakov, A. K., Dreus, A. Yu., \& Lysenko, Ye. Ye. (2014). Study of heat transfer in cryogenic gravel filter during its transportation along a drillhole. Naukovyi Visnyk Natsionalnoho Hirnychoho Universytetu, (6), 49-54.

\section{Математичне моделювання процесів тепломасообміну при розкладенні газових гідратів у пористому середовищі}

\author{
А. Ю. Дреус ${ }^{1}$, В. І. Бондаренко ${ }^{2}$, В. С. Білецький ${ }^{3}$, \\ Р. С. Лисенко
}

1 - Дніпровський національний університет імені Олеся Гончара, м. Дніпро, Україна, e-mail: dreus.andrii@gmail.com 2 - Національний технічний університет «Дніпровська політехніка», м. Дніпро, Україна, e-mail:v_domna@yahoo. com

3 - Національний технічний університет «Харківський політехнічний інститут», м. Харків, Україна

Мета. Розробка методики дослідження та аналіз процесів тепломасообміну в гідратовміщуючому пористому шарі при падінні тиску на його границі.

Методика. Математичне моделювання, обчислювальний експеримент.

Результати. Представлена математична модель теплофізичних процесів при розкладенні газового гідрату в пористому шарі гірської породи. Досліджено випадок розкладення газового гідрату в пористому шарі гірської породи, шо знаходиться у стабільному стані при відносно високих початкових показниках температурі й тиску. Виконані чисельні дослідження полів температури й тиску при розкладенні газового гідрату. Представлено нестаціонарний розподіл температури й тиску вздовж пористого пласта при розкладенні газового гідрату внаслідок падіння тиску на його границі. Визначена швидкість просування фронту розкладення газового гідрату та зміна розмірів області розкладеного газового гідрату переходу у часі.

Наукова новизна. Запропоновано алгоритм розрахунку полів тиску й температури в пористому шарі у випадку, коли температура стабільного газового гідрату вище значення температури його дисоціації. Фактором, що забезпечує процес розкладення газового гідрату, є падіння тиску на границі породного шару. Показано вплив ендотермічної реакції дисоціації газового гідрату на процеси теплообміну в пористому шарі. Показано, що значення температури й тиску, які визначають точку розкладення газового гідрату, змінюються в міру просування фронту фазового переходу.

Практична значимість. Запропоновані математична модель та алгоритм розрахунку можуть бути використані для прогнозування часових характеристик і розмірів зон розкладення газових гідратів навколо експлуатаційних свердловин.

Ключові слова: розкладення газових гідратів, процеси теплообміну, ендотермічна реакція, дисоціація гідрату, падіння тиску

\section{Математическое моделирование процессов тепломассобмена при разложении газовых гидратов в пористой среде}

\section{А. Ю. Дреус ${ }^{1}$, В. И. Бондаренко ${ }^{2}$, В. С. Билецкий ${ }^{3}$, Р. С. Лысенко ${ }^{2}$}

1 - Днепровский национальный университет имени Олеся Гончара, г. Днепр, Украина, e-mail: dreus.andrii@ gmail.com

2 - Национальный технический университет «Днепровская политехника», г. Днепр, Украина, e-mail: v_domna@ yahoo.com

3 - Национальный технический университет «Харьковский политехнический институт», г. Харьков, Украина 
Цель. Разработка методики исследования и анализ процессов тепломассобмена в гидратосодержащем пористом слое при падении давления на его границе.

Методика. Математическое моделирование, вычислительный эксперимент.

Результаты. Представлена математическая модель теплофизических процессов при разложении газового гидрата в пористом слое горной породы. Исследован случай разложения газового гидрата в пористом слое горной породы, который находится в стабильном состоянии при относительно высоких начальных показателях температуры и давления. Выполнены численные исследования полей температуры и давления при разложении газового гидрата. Представлено нестационарное распределение температуры и давления вдоль пористого пласта при разложении газового гидрата вследствие падения давления на его границе. Определены скорость продвижения фронта разложения газового гидрата и изменение размеров области разложенного газового гидрата перехода во времени.

Научная новизна. Предложен алгоритм расчета полей давления и температуры в пористом слое в случае, когда температура стабильного газового гидрата выше значения температуры его диссоциации. Фактором, обеспечивающим процесс разложения газового гидрата, является падение давления на границе породного слоя. Показано влияние эндотермической реакции диссоциации газового гидрата на процессы теплообмена в пористом слое. Показано, что значения температуры и давления, определяющие точку разложения газового гидрата, изменяются по мере продвижения фронта фазового перехода.

Практическая значимость. Предложенные математическая модель и алгоритм расчета могут быть использованы для прогнозирования временных характеристик и размеров зон разложения газовых гидратов вокруг эксплуатационных скважин.

Ключевые слова: разложение газовых гидратов, процессы теплообмена, эндотермическая реакция, диссоциаиия гидрата, падение давления

Recommended for publication by I.A. Kovalevska, Doctor of Technical Sciences. The manuscript was submitted 16.01.20. 